Mitteilungen der Österreichischen Geographischen Gesellschaft, 157. Jg. (Jahresband), Wien 2015, S. 109-128

\title{
Functional Transport Regions in Slovakia Defined by Passenger-Car Traffic Flows
}

\author{
Marcel HoRŇÁK, Bratislava, and Stanislav KRAFT, České Budějovice*
}

with 7 figures and 3 tables in the text

\section{Contents}

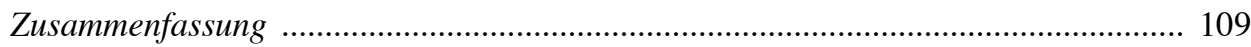

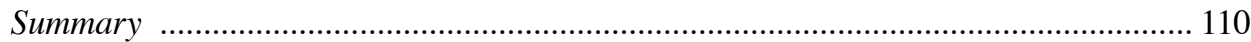

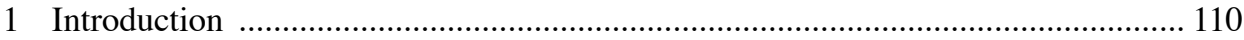

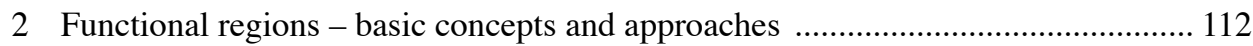

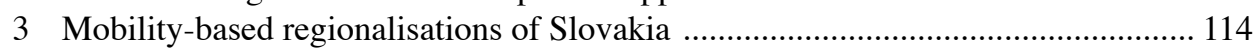

4 The passenger car - key mobility performer in Slovakia ................................... 115

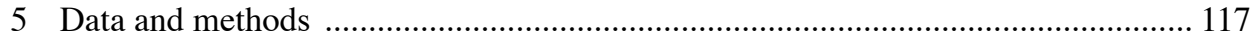

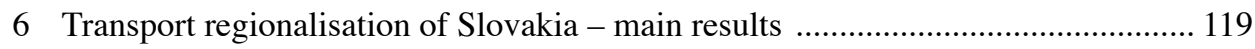

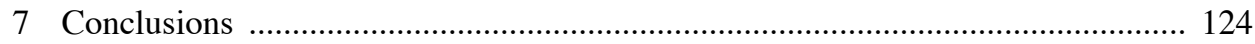

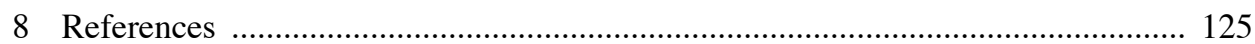

\section{Zusammenfassung}

Funktionale Verkehrsregionen in der Slowakei definiert nach PKW-Verkehrsströmen

Verkehrsbeziehungen sind ein genaues Spiegelbild der wirklichen räumlichen Beziehungen und der zwischenstädtischen Beziehungen. Sie zeigen die Mobilität von Passagieren, Informationen und Gütern, einschließlich der Pendelwanderung, des Pendelns um Dienstleistungen in Anspruch zu nehmen usw. Der Ausweis von funktionalen Verkehrsregionen auf der Grundlage von PKW-Verkehrsströmen ist ein traditioneller Ansatz der

\footnotetext{
* Mgr. Marcel HorŇÁK, PhD., Department of Human Geography and Demography, Faculty of Natural Sciences, Comenius University in Bratislava, Mlynská dolina, Ilkovičova 6, SK-84215 Bratislava; email: hornak@ fns.uniba.sk; http://www.humannageografia.sk; RNDr. Stanislav KraFt, PhD., Department of Geography, Faculty of Education, University of South Bohemia in České Budějovice, Jeronýmova 10, CZ-37115 České Budějovice; email: kraft@pf.jcu.cz; http://www.pf.jcu.cz/structure/departments/kge/

The article was elaborated within the framework of the research grant project "Spatial Dynamics of Transport Relationships in the Settlement System of the Czech Republic", reg. No. 404/12/1035 sponsored by the Czech Science Foundation. It was also supported by The Research and Development Assistance Agency of the Slovak Republic under the contract No. APVV-0018-12.
} 
Geographie, wurde aber in letzter Zeit vernachlässigt. Der Beitrag erklärt, warum es Straßenverkehrsströme verdienen, zum Zwecke des Ausweises von funktionalen Stadtregionen wieder beachtet zu werden und zeigt, dass der Ausweis von funktionalen Verkehrsregionen auf der Grundlage von PKW-Verkehrsströmen eine effiziente Methode ist, die an frühere Ansätze zur Definition funktionaler Stadtregionen in der Slowakei anknüpft. Die Studie verwendet periodische und gut greifbare Daten der Straßenverkehrszählung des Jahres 2010, die in einer GIS-Umgebung interpretiert werden.

Schlagwörter: Straßenverkehr, Verkehrsströme, funktionale Regionen, Verkehrsregionen, Regionalisierung

\section{Summary}

Transport interactions perfectly reflect real spatial interactions and inter-urban relationships. They represent the mobility of passengers, information or goods, including commuter flows, commuting to services, etc. Delimitation of functional transport regions based on passenger-car traffic flows represents a traditional approach in geography, but has recently been neglected. The article explains why road-network traffic flows should be reconsidered for the purposes of delimiting functional urban areas (FUAs) and demonstrates that delimitation of functional regions based on passenger-car traffic flows is an efficient way corresponding to former approaches to the delimitation of functional urban regions in Slovakia. This study utilises periodical and well-available road-traffic survey data as of 2010, interpreted in GIS environment.

Keywords: road transport, traffic flows, functional regions, transport regions, regionalisation

\section{Introduction}

The issue of delimiting functional regions and functional regional taxonomy has traditionally been one of the key topics in human geography. DZIEWOŃSKI (1967) presented three elementary approaches to research on regions in human geography: the region as an object of geographical research, the region as a tool of geographical research and the region as a tool necessary for spatial management. The aim of the first approach is spatial delimitation of the region based on elementary or more sophisticated criteria or methods, while the two latter ones primarily use statistical and administrative regions as objects of further analyses (see the discussion in KLAPKA et al. 2014). In many countries, where the implementation of administrative units has gone a wrong way, functional regions are explicitly utilised for regional analyses.

Slovakia certainly ranks among such countries, therefore the concept of functional urban regions derived from travel-to-work commuting flows introduced by BEZÁK (1990, 2000) has frequently been applied in numerous studies published thereafter (KOREC \& Ondoš 2006; Šveda 2010; NovotnÝ 2011; Korec \& PolonyovÁ 2011; Tóth 2014, etc.). 
Functional urban regions are perceived as units, which correspond to the spatial differentiation of socio-economic activities and inter-urban relationships in a country much better than administrative units (districts - LAU-1, NUTS-4). Moreover, functional urban regions clearly account for traditionally perceived centre-periphery polarisation (see CoPUS 2001; Hampl 2005; MichniaK 2005 or HAVLíčEK et al. 2008), while Slovakia's official administrative units tend to equalise polarisation. This is the reason why functional urban regions frequently appear in Slovakian geographical research.

The main obstacle when dealing with functional urban regions in Slovakia stems from the fact that they are mostly based on daily commuting-to-work data. In many studies, the commuting-to-work database has been applied as the only data source. Commuting to work is still regarded as the most important element of inter-urban interactions at micro-regional level and one of the key region-shaping processes (e.g., KARLSSON \& Olsson 2006 or SÝKORA \& MuLíčEK 2009).

It seems, however, that this indicator has recently become less relevant. One of the reasons may be the lack of relevant and reliable data. For example, in Slovakia the recent population census witnessed imperfections in detection of work-migration volumes. $\mathrm{Nu}$ merous researchers criticise excessive confidence in travel-to-work data for delimiting functional regions (e.g., SoHn 2005). Several recent studies demonstrate also a set of more appropriate indicators leading to delimiting functional regions (e.g., NovÁK et al. 2013 or KRAFT, HALÁs \& VANČURA 2014).

Our study has several aims. It is firstly an attempt to identify functional regions in Slovakia based on transport interactions. We consider transport interactions as key indicators of spatial relationships, as perfectly reflecting inter-urban interactions (commuting, business interactions, services relationships, etc.). In our opinion, these interactions are much more comprehensive than pure travel-to-work data as applied in most studies aimed at delimiting functional regions. Secondly, we compare such transport regions based on transport-interactions with existing delimitations of functional regions published so far and with the existing administrative-territorial units of Slovakia. This comparison will perhaps answer the basic research question, whether (and to what extent) transport interactions reflect the complexity of spatial interactions.

The functional region concept based on the intensity of transportation flows is not at all new in human geography, but has recently rather been neglected. It is our intention to revive the discussion on it and to stress its applicability in real-life decision-making processes. Recognising the fact that road transport plays the key role in mobility in most developed countries, we decided to apply the indicator of passenger-car transport intensity for delimiting functional transport regions in Slovakia. The results of the study might be interesting not only for human geography, but also for regional and urban planning, transport engineering, transport economics, etc. Some of the results may be inspiring for authorities and decision-makers, too.

The article will at first highlight the relevance of functional regions in general. Then, principal concepts of transport regionalisation and transport regions will be evaluated, including specific types of functional regions. Recent trends in transport development in 
Slovakia will be analysed to explain the role of car transport in the Slovakian society in the context of recent social and economic developments. Special attention will be paid to the delimitation of transport regions in Slovakia utilising their basic statistical attributes for comparison with other territorial regionalisations of Slovakia. The final chapter will present a synthesis of the issue and recommendations for further research.

\section{Functional regions - basic concepts and approaches}

Functional regions belong to the basic concepts of regional geography (CLAVAL 2007). Functional regions are organised by the intensity and direction of functional spatial flows. So-called nodal regions characterised by functional relations around urban cores are considered as the most frequent variant of functional regions. They are shaped primarily through interactions between cores and their hinterlands. These interactions may be of various nature: physical flows of people and goods, or less evident flows of information or money. Core and hinterland are integral parts of functional regions and their existence is conditioned by unequal distribution of economic and social activities in space, which generate functional interactions between each other. Therefore, at the micro-regional level we most often observe polarisation between core cities/towns and their hinterlands. Functional regions based on the intensity of spatial interactions can be defined practically at all hierarchical levels, from local to global. Our article, however, will primarily focus on the micro-regional level, which reflects the aforementioned core-hinterland polarisation most apparently. Polarisation on the micro-regional level is traditionally generated by the daily flow of people. This is why daily commuting is usually used to identify micro-regions (e.g., BEZÁK 2000 or SÝKORA \& MuLíčEK 2009).

From a methodical point of view, basically two issues have to be addressed, when it comes to defining functional regions. These are the selection of the proper cores and the selection of the appropriate interaction indicators. Both have been examined in detail in numerous studies (e.g., Karlsson \& Olsson 2006 or CASAdo-Diáz \& CoOmbes 2011). Therefore, we will further focus only on issues related to transport regionalisation. Traditionally functional regions are defined by using data on commuting to work, commuting to services, migration flows, etc. Most attention is paid to defining regions based on commuting to work (e.g., daily urban systems, travel-to-work areas, functional urban areas, local labour-market areas). Many authors describe commuting as a key process of region formation, which occurs based on daily commuter flows from hinterlands to cores (e.g., HAMPL, GARDAVSKÝ \& KüHNL 1987). The key principle of regionalisation based on commuting is the division of a larger territory into smaller units integrated with cores based on the intensity of commuter flows. First attempts to define commuter regions appeared in the 1940s (CASAdo-Dí́z \& CoOmbes 2011). However, these traditional methods have recently been subjected to harsh criticism.

The main points of criticism of traditionally defined functional regions based on commuting have an ambiguous nature. Some criticise the traditional method of regionalisation, which is labeled as a top-down method. By the top-down approach, the cores of regions are defined first, and then their hinterlands are delimited usually by the most 
prominent commuting flows. This method is criticised for its arbitrary pre-definition of the cores based on structural characteristics of size (KLAPKA et al. 2014). From a practical point of view, numerous studies have shown that this traditionally used top-down method strongly overestimates the importance of large centres to the detriment of weaker ones, which in fact may have significance in the spatial distribution of commuter flows (HALÁs et al. 2010).

For this reason, we increasingly find studies based on the opposite approach, known as bottom-up method (COOMBES \& OPENSHAw 1982). Its basic principle is a stronger consideration of the real significance of commuter centres and their autonomous character. Within the bottom-up method, clusters of commuting links with relative autonomy are first identified, and only in the subsequent phase the cores of regions are defined. In practice, this method better reflects the significance of a region's coherent character and autonomy. In many cases it confines the regional influence of large commuter centres to the benefit of smaller regional units.

Another significant criticism of traditional approaches to regionalisation is the one that emphasises commuting relations as complex spatial interactions. SoHN (2005), e.g., concludes that commuter flows are increasingly overshadowed by new phenomena such as home-office work, work without a specific constant workplace, relocation of workplaces from cities to suburban zones, etc., which make it more difficult to recognise the previously clear, direct and radial interactions with cores. Therefore, it is said, commuter flows reflected the complex spatial relations less than previously. Moreover, many studies focusing on general mobility in various countries point out that nowadays commuting to work is the less significant part of daily movements. In Western countries, the share of trips undertaken during commuting to work ranges today between 20 and $30 \%$, and in the former Communist countries of Central and Eastern Europe with fewer cars this share amounts to around 40\% (LAYOS 2005). Based on what has been stated, it can be assumed that commuter flows today are significant, but not comprehensive indicators of core-hinterland relations. Overall daily spatial mobility of people, goods and information may be considered as more comprehensive than just commuter flows. We should also mention some innovative approaches, such as by NovÁk et al. (2013), who defined functional regions using mobile phone localisation data, which document overall daily mobility and may provide detailed information on human mobility.

As mentioned above, the concept of delimiting functional regions derived from transport interactions is not new at all. First such attempts appeared in the 1920s and 1930s (Aso 1929). The peak of transport-regionalisation studies was reached in the 1950s and 1960s, when numerous inspiring studies were published (such as GREEN 1953; GodLuND 1956; SÄNTTI 1954). Respecting the nature of that period it is obvious that transport indicators were considered as basic attributes of complex spatial interactions, since commuting to work was not a matter of systematic surveys until the second half of the $20^{\text {th }}$ century.

In former Czechoslovakia, e.g., commuting-to-work frequencies were first documented by the 1961 population census and systematically from 1970 onward. Frank GrEEN (1958, 1966) is generally considered as a pioneer in applying transport-regionalisation methods utilising data on bus-service networks. Identification of centres and their hinter- 
lands as well as so-called shift (peripheral) zones was based on the cartographic method of frequency diagrams. HŮRskÝ (1978) and BranickÝ \& MLÁdeK (1991) later introduced the issue of transport regionalisation into Czechoslovak geography.

In the 1970s, when the number of studies grew and more sophisticated methods based on commuter-flow analyses had been introduced, functional transport regions became increasingly neglected. The main advantage of commuter-based surveys is their periodicity, complexity and spatial preciseness of data.

Recently, functional transport regions are quite rarely in the focus of scientific research, although we should mention for example JoRDAN $(1984,1995)$ or KRAFT, HALÁs \& VANČURA (2014). However, as mentioned above, reduced reliability of the commuter-flows database, growing relevance of individual mobility and thus higher complexity of transport interactions accompanied by the evolution of GIS methods might lead us to foresee a possible revival of the functional transport-regionalisation approach as an alternative applicable in regional taxonomy (delimitation of urban hinterlands, delimitations and revisions of administrative territorial units, etc.). The main advantage of such an approach is based on the fact that most micro-regional interactions are realised by individual mobility due to increasing household motorisation and growing individual mobility. Passenger car-traffic flows are potentially applicable for delimiting functional regions at a high level of complexity. They cover work-commuter flows, commuting to services, business interactions, leisure time journeys, etc.

\section{Mobility-based regionalisations of Slovakia}

No matter what indicator is utilised to delimit the boundary of functional regions, most of the existing studies follow mobility-related interactions (labour commuters, accessibility approach, transport interactions, etc.). A survey of the past studies on transport-regionalisation attempts may be inspiring and may also provide for clues to a comparison of some of the most relevant functional regionalisations of Slovakia (see Table 1). Therefore, in this part of the article, some of the most inspiring mobility- and transport-related regionalisations will briefly be presented.

The studies of BRANickÝ (1986) and BRANiCKÝ \& MLÁDEK (1991) represent the first attempts of a detailed transport regionalisation of Slovakia based on multiple criteria. The first step was the identification of 53 principal passenger- and freight-transport cores in the country, considering the frequency of public transport services and haulage volumes (in both road and railway networks) in individual transport nodes based on statistics referring to the years between 1980 and 1983. The hinterlands of such nodes were then delimited based on the territorial organisation of passenger public (bus) transport. A strong argument for this procedure is the fact that the generous network of regional public bus transportation in the beginning of the 1980s reflected perfectly intra-regional spatial relationships. This approach resulted in the aggregation of 2,900 Slovakian municipalities to 53 transport micro-regions. The 53 micro-regions were merged into 15 meso-regions, and the top level was represented by six so-called mega-regions with six relevant transport cores. In the context of our study it is worth mentioning that the model of these 53 micro-regions 
is very similar to the results of some later studies, although they used different databases and methods.

Nodal relationships as the principal pattern of regional structures have been shown by BEZÁK (1990, 2000), who emphasised the role of spatial (nodal) migration flows between the core and its hinterland. Based on daily migration flows to nodal cores derived from national 1991 and 2001 census surveys, he delimited 60 to 66 nodal regions in Slovakia. These regions may be considered as regional labour markets (see BEZÁK 2001). They partly reflect a certain complexity of intra-regional functional relationships (BEZÁK 2014).

A 2011 census data analysis of KATUŠA \& SOPKULIAK (2013) was inspired by the methodology of BЕZÁK (2000) and identified 62 regions.

\begin{tabular}{|l|l|c|}
\hline Author(s) & \multicolumn{1}{|c|}{$\begin{array}{c}\text { Methodological approach to } \\
\text { regionalisation }\end{array}$} & $\begin{array}{c}\text { Number of re- } \\
\text { gions delimited }\end{array}$ \\
\hline BRANICKÝ \& MLÁDEK (1991) & Regional bus-networks range & 53 \\
\hline BEZÁK (1990, 2000) & Daily travel-to-work flows to nodal centres & $60-66$ \\
\hline KATUŠA \& SOPKULIAK (2013) & Daily travel-to-work flows to nodal centres & 62 \\
\hline HALÁS et al. (2014) & Daily travel-to-work flows within the regions & 47 (39-65) \\
\hline
\end{tabular}

Tab. 1: Comparison of selected approaches to regionalise Slovakia based on mobility-related indicators

The concept of functional regions respecting daily commuting to work was later applied by HaLÁs et al. (2014), who adopted the former approach of BEZÁK (2000) and applied a slightly modified concept of regional labour markets. HALÁs et al. took the inner work-commuter flows into consideration and identified three different regional systems (FRD - functional regions based on daily travel-to-work flows) by applying three various settings of minimum population size and self-containment level. The FRD-1 system is represented by 65 functional regions, named by HALÁs et al. as local labour markets, while the FRD-3 system consists of 39 larger regions, identical with regional labour markets.

All studies mentioned above refer to a similar number of territorial units (39-66). Not surprisingly, spatial patterns and delineation of regional boundaries show a lot of similarities. We agree with statements of HALÁs et al. (2014) that especially in the northern part of the country the regional boundaries correspond to natural boundaries generated by the morphology of the Carpathians [Karpaty], while in the south the lowlands allow the blurring of boundaries. Thus, the morphology of northern Slovakia results in a high similarity of nodal regions or daily urban systems, no matter what approach is used for delimiting such regions.

\section{The passenger car - key mobility performer in Slovakia}

Individual mobility growth in post-industrial societies is evident and calls for higher intensity of passenger-car use even in post-Socialist countries (PUCHER \& BUEHLER 2005). As stated by FAITH (2008), the increase of individual mobility and passenger-car utilisation in Slovakia has been supported by social and economic changes, especially the growing 
Gross Domestic Product and increasing household incomes, and also by deep structural changes of the country's economy, which is now dominated by the tertiary sector eliciting higher demand for individual mobility. In many rural regions affected by the public passenger transport reform the passenger car has certainly become an inevitable 'family member', as shown for instance by HoRŇ́́K \& ROCHOVSKÁ (2014).

\begin{tabular}{|l|r|r|r|r|r|r|r|r|}
\hline & $\mathbf{1 9 9 0}$ & $\mathbf{1 9 9 5}$ & $\mathbf{2 0 0 0}$ & $\mathbf{2 0 0 5}$ & $\mathbf{2 0 1 0}$ & $\mathbf{2 0 1 1}$ & $\mathbf{2 0 1 2}$ & $\mathbf{2 0 1 3}$ \\
\hline $\begin{array}{l}\text { Total number of road } \\
\text { vehicles (in 1,000) }\end{array}$ & 1,527 & 1,498 & 1,752 & 1,801 & 2,339 & 2,442 & 2,538 & 2,623 \\
\hline $\begin{array}{l}\text { Number of passenger } \\
\text { cars (in 1,000) }\end{array}$ & 876 & 1,016 & 1,274 & 1,304 & 1,669 & 1,749 & 1,824 & 1,880 \\
\hline $\begin{array}{l}\text { Passenger cars per 1,000 } \\
\text { inhabitants }\end{array}$ & 165 & 189 & 236 & 242 & 307 & 324 & 337 & 347 \\
\hline
\end{tabular}

Source: Ministry of Transport, Construction and Regional Development of the Slovak Republic, Statistical Office of the Slovak Republic

Tab. 2: Passenger-car stock development in Slovakia in the post-Socialist period

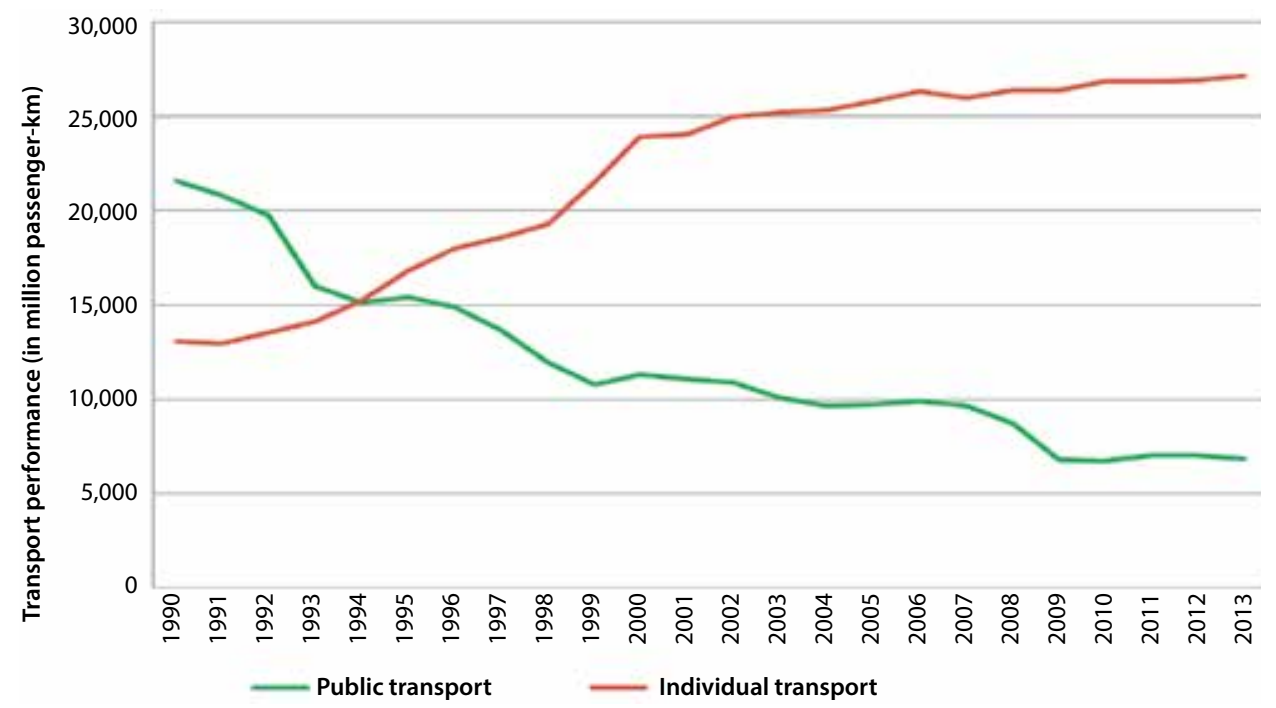

Source: Ministry of Transport, Construction and Regional Development of the Slovak RepubLIC

Fig. 1: Public transport and individual transport performance trends (in mio. passenger-km) in Slovakia

Notwithstanding the harmonic balance between public and individual means of transport in the Socialist period, the Slovak society is unambiguously following the west-European trends and has become very dependent on passenger cars. The number of registered 
passenger vehicles has more than doubled since 1990 (Table 2). Not surprisingly, soon after the collapse of Communism, individual road transport became the key mobility performer in Slovakia (see Fig. 1), especially in intra- and inter-regional passenger transport (see FAith 2008).

These facts lead to the conclusion that - provided that proper tools of monitoring are available - this may be a rich source of spatial interactions data, also taking into account that it is nowadays supported by the development of IT and GIS technologies (see RINZIVILLO et al. 2012). Research in individual mobility has been increasingly utilised to detect territorial interactions in post-Socialist countries (see for example KONJAR, LISEC \& DROBNE 2010; Kraft \& Vančura 2010; Kraft, Halás \& VanČUra 2014; Selivanova 2012; etc.).

\section{Data and methods}

Our analysis is based on passenger-car traffic flows in Slovakia. In our opinion, these flows represent the key element of the country's transport system and may help reveal spatial interactions. According to 2011 census data, the passenger car is the dominant transport mode employed by commuters to work in Slovakia. Over $45 \%$ of commuters to work use cars, only $39 \%$ public transport (train, bus or urban transport).

As in most post-Communist countries, data illustrating passenger-car traffic flows in Slovakia are available only by national road-traffic censuses, executed every five years. Their advantages are their nation-wide extent, their periodicity and high spatial accuracy as well as their spatial preciseness related to a substantial part of the road network (KRAFT, MARADA \& PopJAKovÁ 2014). These periodic surveys are based on a simple computation of passenger-car loads by road sections, while information on initial and terminal points of individual journeys or vehicle occupancy is missing. Passenger-car traffic flows usually concentrate on urban cores, while in rural space they are rather dispersed, which clearly reflects the urban-rural polarisation of space (Fig. 2).

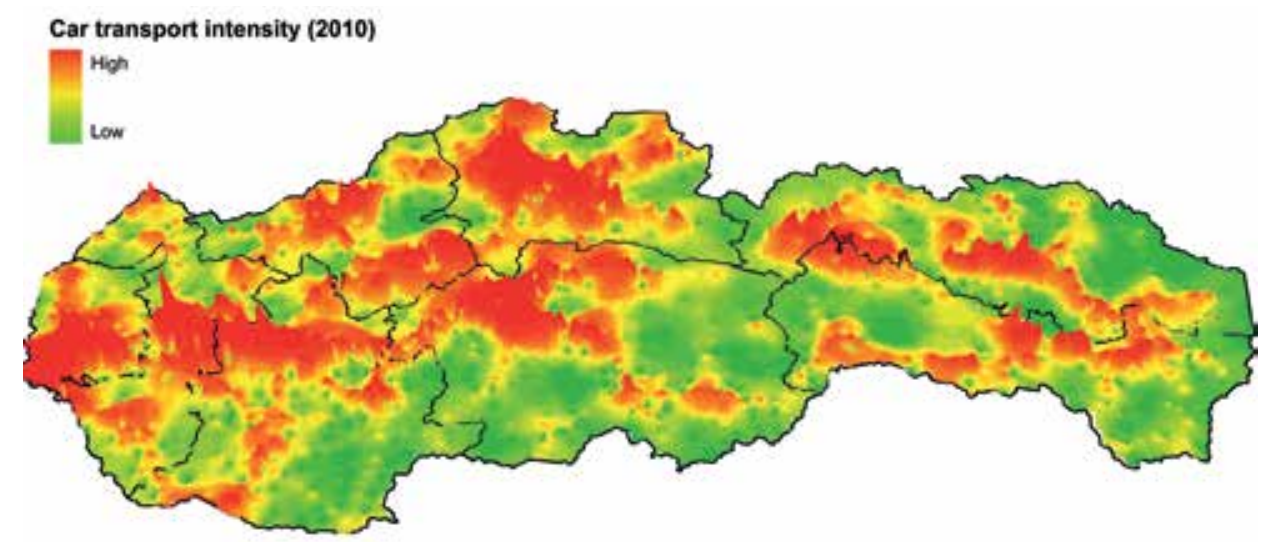

Source: ROAD-TRAFFIC CENSUS 2010

Fig. 2: Extrapolation of road-transport intensities in Slovakia 2010 
According to our research, the nodal structure has recently been accentuated. Passenger-car traffic flows in urban cores and their near hinterland grow more rapidly than in the periphery. Thus, the polarity of core-periphery transport interactions at the micro-regional level has been increasing, which lets the coherence within micro-regions grow. These facts support our assumption that data on passenger-car traffic loads represent a unique source perfectly applicable for delimiting transport regions and the regional impact of urban cores. For the purposes of this study, the 2010 road-census database was utilised. Only expressways, $1^{\text {st }}$ class and $2^{\text {nd }}$ class roads were included in our study, assuming that these road-network segments carry most of the regional transport volumes.

The method developed for this paper was inspired by previous studies focused on transport regionalisation issues. Among others, we should mention GREEN (1953, 1958, 1966) and GODLUND (1956), later HŮRSKÝ (1978) and recent studies by JORDAN (1995) or Kraft, Marada \& Popjaková (2014). All these studies have been inspiring in designing the methodology of delimiting transport regions in Slovakia. Special attention was paid to HŮRSKÝ (1978), who introduced what is today known as the saddle identification. He defines the saddle point as the section of the road network, where the traffic load reaches a local minimum and is lower than in the neighbouring road-network sections. The local minimum concept is based on the assumption that the traffic load at the saddle is generated by interactions between higher levels of the regional settlement hierarchy, i.e., transit flows, not intra-regional interactions.

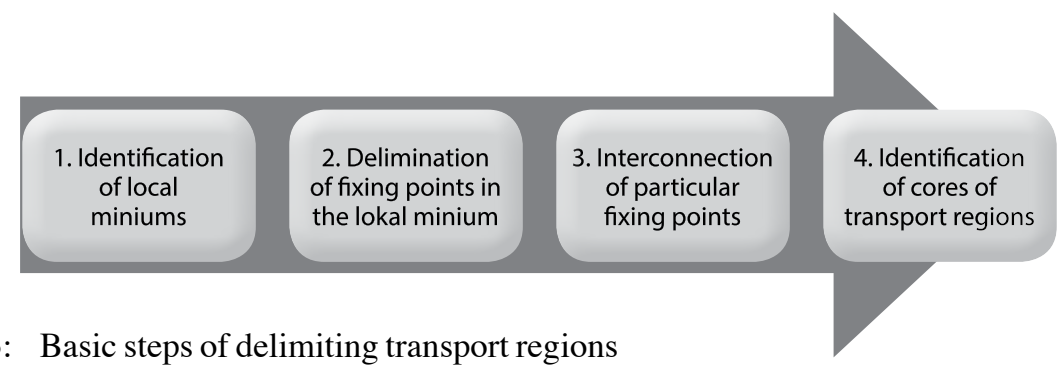

Fig. 3: Basic steps of delimiting transport regions

The procedure of delimiting regions consist of four basic steps (Fig. 3). First, the local minimum (saddle) points are identified. In the second phase, a network of fixing points is generated. A fixing point divides at a saddle between neighbouring traffic-flow sections. In the third step the fixing points are connected to coherent boundary lines. They do not necessarily respect the boundaries of municipalities. The final step is the identification of the cores of the transport regions.

The advantage of this bottom-up approach in the process of identification of cores stems from the fact that in some cases the definition of saddle points between arbitrarily defined centres is almost impossible (see for example attempts of HŮRsKÝ 1978). Our method, however, enables to identify regions unambiguously, since they are delimited by local minimum points.

The main result of this procedure is a map layer with transport regions, which was then compared with selected five other approaches of regionalising Slovakia. Out of numerous 
attempts, we finally decided to compare our transport regions with the following other regionalisations as regards territorial congruence:

- LAU-1/NUTS-4 units (districts) - functioning as statistical and partly administrative units since 1997;

- BЕZÁK (2000) - functional urban regions, delimited on 1991 census data and based on work-commuting flows;

- Slavík \& BAČí́ (2007) - micro-regions (160), based on municipal competencies. The study serves as a database for an intended municipal reform in Slovakia.

- Halás et al. (2014) - functional urban regions, based on 2001 census data, delimited by a slightly upgraded methodology of BEZÁK (2000);

- Katuša \& SopkUliaK (2013) - functional urban regions, based on 2011 census data, delimited by an adjusted methodology of BEZÁK (2000).

\section{Transport regionalisation of Slovakia - main results}

The final output map with the transport regions delimited by our approach shows that their areas vary significantly in size (Fig. 4). The total number of transport regions identified is 98 . Passenger-car traffic intensity within the regions clearly grows in the boundary-core direction, with the cores being burdened with the highest traffic loads. Thus, it perfectly reflects the micro-regional core-hinterland polarisation.

In most cases the area of a transport region corresponds to the size of the core. Larger transport regions occur in the mountainous central Slovakia, where morphology (rough mountain ranges forming natural boundaries between nodal regions) and low density of nodal urban centres do not allow fragmentation of human activities into very small nodal

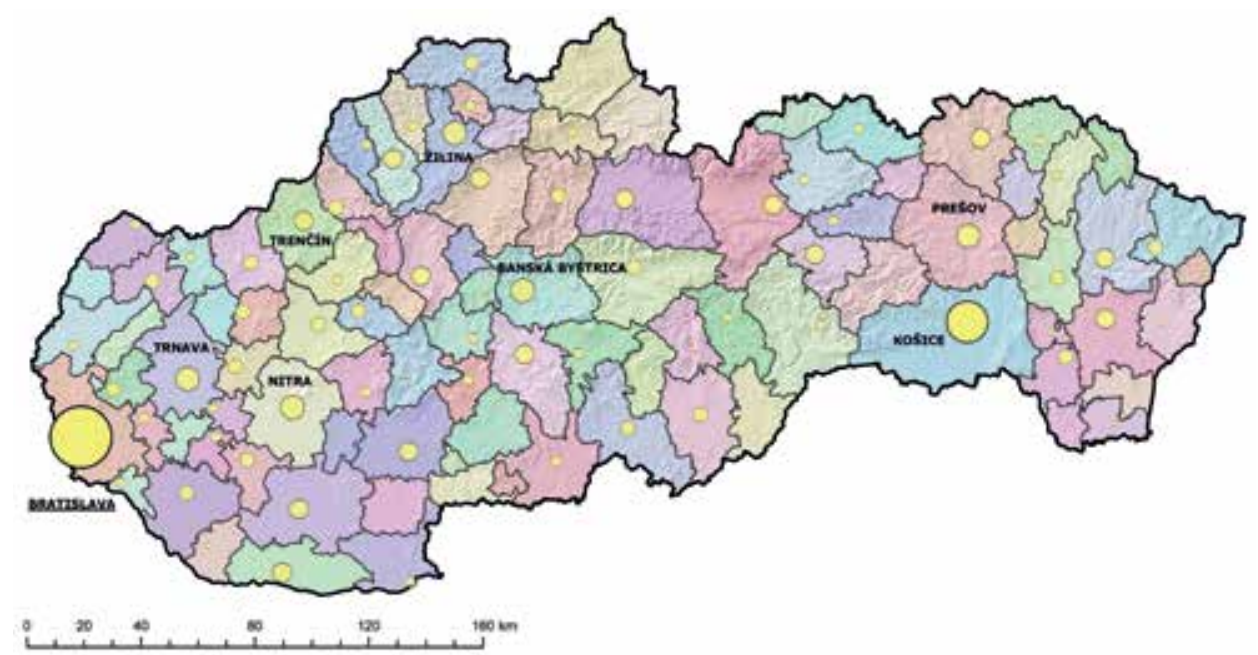

Source: RoAD-TRAFFIC CENSUS 2010

Fig. 4: Transport regions in Slovakia 2010 


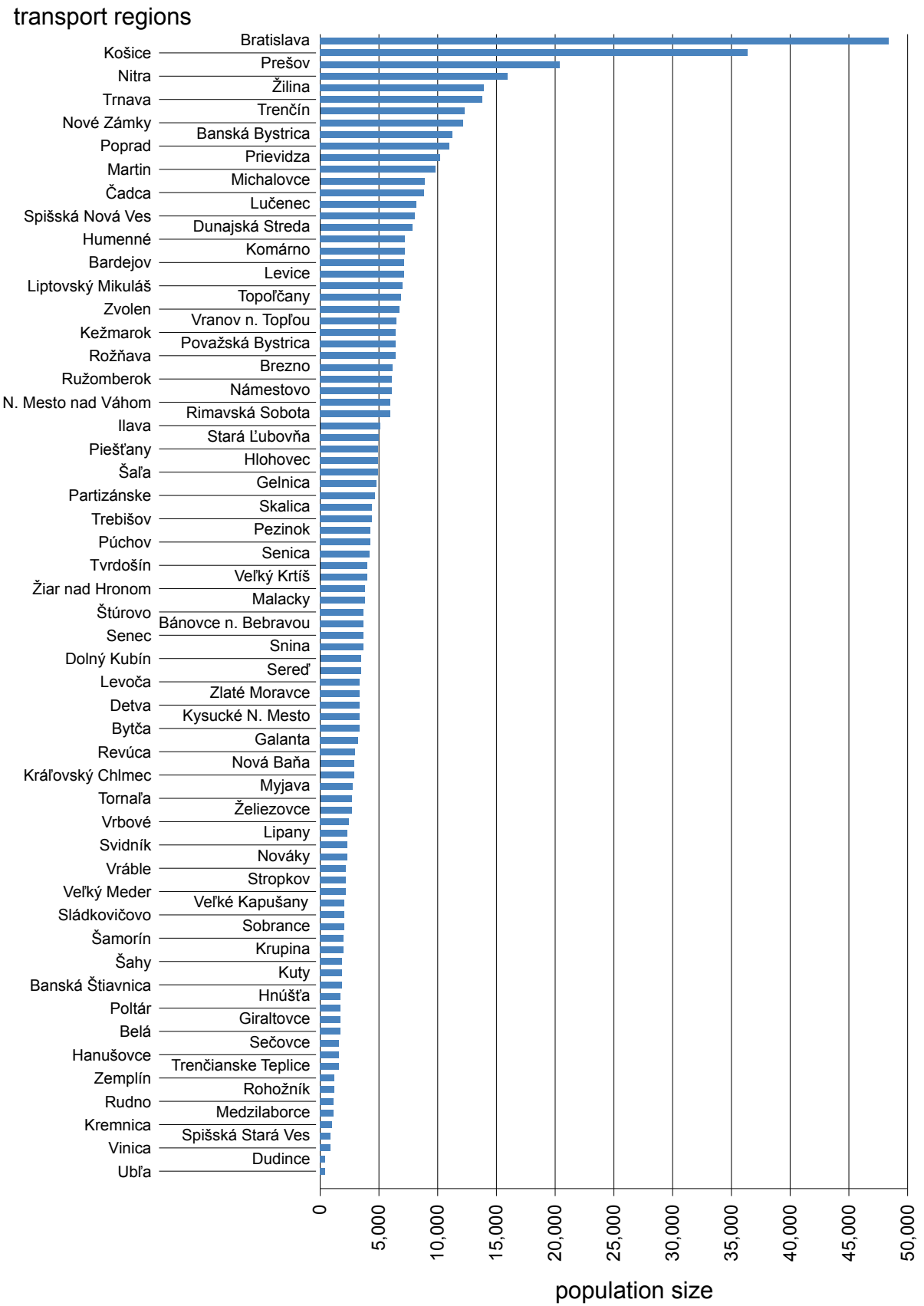

Sources: RoAD-TRAFFIC CENSUS 2010, PopUlation AND HOUSING CENSUS 2011

Fig. 5: Population size of Slovakian transport regions 
regions. In contrast to previous regionalisations, where all cores are urban, the nodal centres of eight transport regions are non-urban cores. We should emphasise that our transport regions reflect not only the commuting-to-work interactions, but show also frequent commuting to services or shopping centres as other important region-formation processes (see, e.g., HalÁs \& ZusKáčová 2013 or MARYÁš et al. 2014).

The population size of our transport regions (see Fig. 5) varies between 485,000 (Bratislava region) and 2,447 (Ubl'a region). The size criterion was not decisive in this approach. Similarly, the population size of the transport region does not always reflect the size of its nodal centre, since nodality and gravity of nodes in real geographical space are affected by a wide complex of factors such as morphology and natural barriers, historical interactions, structural changes of local economies and regional labour markets, transport position, road-network density, settlement and regional specifics, etc. Nevertheless, it is evident that larger urban cores tend to generate larger hinterlands with more inhabitants.

Figure 5 clearly indicates the dominant position of prominent Slovakian metropoles (Bratislava and Košice) with transport regions exceeding 300,000 residents. The top transport regions in terms of population size are formed by all regional centres of Slovakia. But the population number of these regions correlates not merely with the size of the cores, it depends also on population density and population size of the municipalities in the hinterlands. The bottom of the size chart is occupied by regions with either very small and weak urban cores (such as Dudince, Spišská Stará Ves) or rural centres (e.g., Vinica, Ubl'a). Statistical analysis of the core- and hinterland-size relationship shows a linear dependence (Fig. 6). Morphology and settlement specifics in some regions contribute to

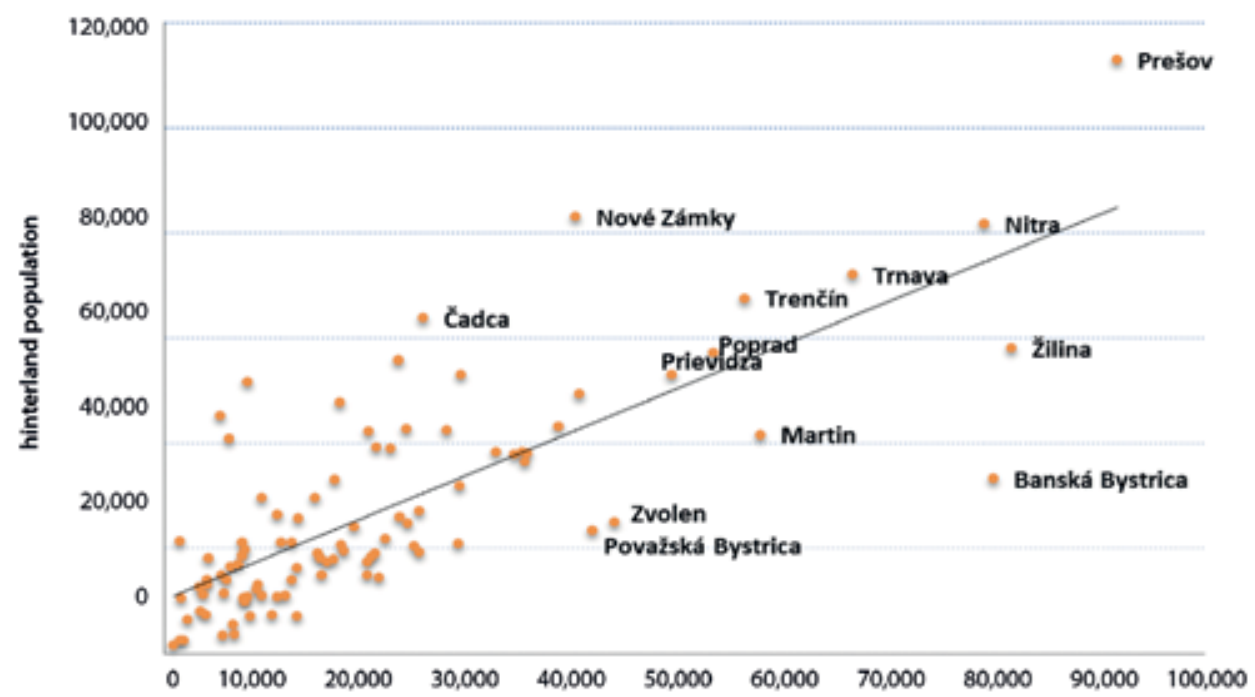

Sources: RoAD-TRAFFic CENSUS 2010, PopULATION AND HOUSING CENSUS 2011

Fig. 6: Transport regions in Slovakia: statistical relationship between the sizes of core and hinterland (Bratislava and Košice excluded) 
the variability of the core-hinterland relation in size. In the case of urban cores located in narrow basins of the Carpathians in central Slovakia (such as Žilina, Banská Bystrica or Martin), the hinterland population size is relatively small, even if the urban cores have many inhabitants. In contrast, cores located in the open lowlands of the south-west (Nitra, Trnava or the smaller Nové Zámky) or in the densely populated area of eastern Slovakia, where they are rather distant from each other (e.g., Prešov), they tend to generate larger hinterlands.

Not surprisingly, transport regions delimited in this way are rather similar to previous regionalisation attempts. If the various regionalisations are cartographically compared, it is easy to see the extent of their territorial congruence (see Fig. 7). Areas, where our transport regions fully coincide with the respective other regionalisation, are indicated by full colours. White symbolises areas, where our region deviates from the respective regionalisation.
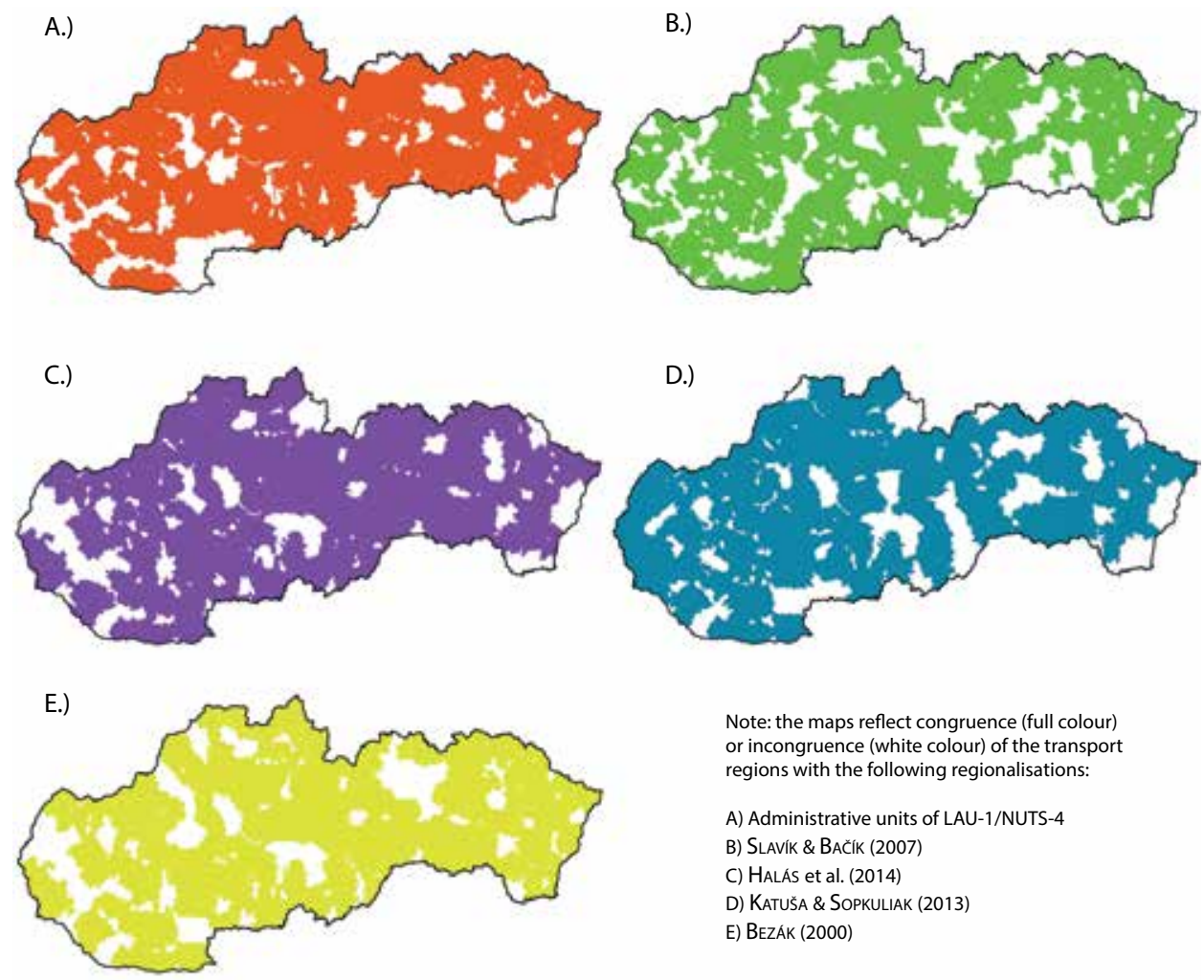

Note: the maps reflect congruence (full colour) or incongruence (white colour) of the transport regions with the following regionalisations:

A) Administrative units of LAU-1/NUTS-4 B) SLAVÍK \& BAČíK (2007)

C) HALAS et al. (2014)

D) KATUŠA \& SOPKULIAK (2013)

E) BEZÁK (2000)

Sources: Road-TRAFic census 2010; BezÁK (2000); Slaví́ \& BaČík (2007); KatušA \& Sopkuliak (2013); HaLÁs et al. (2014)

Fig. 7: Comparison of our transport regionalisation with other approaches to delimiting functional regions in Slovakia 
Comparison of the maps in Figure 7 shows that the northern part of central Slovakia with undisputedly clear morphological boundaries is more congruent than other parts of the country, where mild morphology and numerous urban cores contribute to generate somewhat volatile territorial structures.

This is confirmed also by statistical comparison measuring the percentage of similarity calculated on the basis of three elementary parameters: number of municipalities, population size and area size of the areas of congruence (Table 3 ). It reveals that the lowest extent of congruence exists with the model of municipal micro-regions delimited by SLAVík \& B Ас̌́́к (2007). This is primarily due to the high number of identified regional units (160) in this model. In contrast, high congruence is achieved with the regionalisations presented by BEZÁK (2000) and HALÁs et al. (2014), which may also be taken as a proof of the correctness of our approach. Our transport regionalisation as well as the studies of BEZÁK and HALÁs et al. are rooted in the same or a very similar database (census data) reflecting mobility flows. Similarity with these studies also shows that these flows seem to be quite stable in time, since the study by BEZÁK (2000) is based on 1991 census data. The question of temporal stability of mobility flows, however, calls still for more detailed studies.

\begin{tabular}{|l|c|c|c|c|c|c|c|}
\hline \multirow{2}{*}{$\begin{array}{c}\text { Approach/ } \\
\text { author(s) }\end{array}$} & \multirow{2}{*}{$\begin{array}{c}\text { Num- } \\
\text { ber of } \\
\text { re- } \\
\text { gions }\end{array}$} & \multicolumn{2}{|c|}{$\begin{array}{c}\text { Number of } \\
\text { municipalities }\end{array}$} & \multicolumn{2}{c|}{ Population } & \multicolumn{2}{c|}{ Area size (in km²) } \\
\cline { 5 - 9 } & abs. & $\begin{array}{c}\text { \%o of } \\
\text { the } \\
\text { total }\end{array}$ & abs. & $\begin{array}{c}\text { \% of } \\
\text { the } \\
\text { total }\end{array}$ & abs. & $\begin{array}{c}\text { \% of } \\
\text { the } \\
\text { total }\end{array}$ \\
\hline $\begin{array}{l}\text { Administrative regions/ } \\
\text { districts (LAU-1/ } \\
\text { NUTS-4) }\end{array}$ & 79 & 2,098 & 72.6 & $4,443,485$ & 82.3 & 36,612 & 74.7 \\
\hline BEZÁK (2000) & 66 & 2,236 & 77.4 & $4,439,673$ & 82.3 & 37,619 & 76.7 \\
\hline SLAVÍK \& BAČ́́K (2007) & 160 & 2,036 & 70.4 & $4,318,161$ & 80.0 & 34,362 & 70.1 \\
\hline HALÁS et al. (2014) & 65 & 2,288 & 79.2 & $4,614,266$ & 85.5 & 38,164 & 77.8 \\
\hline $\begin{array}{l}\text { KATUŠA \& SOPKULIAK } \\
\text { (2013) }\end{array}$ & 62 & 2,198 & 76.1 & $4,617,857$ & 85.6 & 37,169 & 75.8 \\
\hline
\end{tabular}

Source: Population AND housing CENSUS 2011

Tab. 3: Extent of congruence of selected regionalisation approaches with our transport regionalisation $($ values $=$ parameters of overlaid areas)

More attention should also be paid to reforms of the territorial-administrative division of the country. The approach presented in this paper supports the criticism of the existing system of districts (LAU-1/NUTS-4 units) in Slovakia, which does not respect geographical regions shaped by nodal interactions. As illustrated in Figure 7, especially the belt of districts along the southern border with Hungary shows high incongruence with our transport regions. This finding corresponds with claims of KoREC et al. (2005) or BEZÁK (2000), who criticised the territorial-administrative reform of 1997. Unfortunately, 
recent national planning documents (such as the National Spatial Planning Development Perspective, known as KURS 2001) very often insist on existing administrative units (usually of the NUTS-4 level), which caused us not pay special attention to this matter in this contribution.

\section{Conclusions}

Delimitation of appropriate complex functional regions based on proper human geography parameters has been in the focus of numerous studies for a few decades. The accurateness of each delimitation depends on the selection of a set of indicators that would describe the real geographical interactions as perfectly as possible. Most of the recent studies are rooted deeply in the functional region concept considering the core of the region and its hinterland. This elementary spatial inequality generates tensions resulting in flows measurable by various indicators. Researchers in the post-Communist societies of East-Central Europe increasingly use work-commuter volumes, easily available from the regular population census databases.

Criticism of such approaches was not the main goal of this study. We rather intended to resuscitate an alternative method, based on an easily accessible database and introduced by HŮRSKÝ (1978). One of the key advantages of this method using passenger-car traffic flows is availability of the source data updated in five-year intervals.

The main results of our study are the following:

- Delimitation of functional regions (transport regions) based on passenger-car traffic flows seems to be a fruitful approach; availability of source data and geographically identifiable data on traffic flows make this method very effective.

- Our regionalisation is based on the comprehensiveness of its principal indicator: The volume of passenger-car traffic flows includes not only regular commuters to work, but all movements within the respective road section, including for instance shopping or school commuters.

- Our regionalisation applied to Slovakia using the 2010 road-census data has identified 98 transport regions, with the Bratislava region being the most populated (nearly 500,000 residents) and the Ubl'a region in eastern Slovakia being the smallest $(2,500$ residents).

- Our regionalisation shows high propinquity with other models of functional regions for Slovakia, especially with the mobility-related models of functional urban regions calculated on the population census work-commuter flows.

- Some other transport-related inputs might be used for delimiting functional regions (such as networks of regional public transport) probably resulting in a different structure. This might stimulate further research.

Further research might focus on the stability of transport regions over time. This fact is one of the principal issues in regionalisation approaches, no matter what input data are applied. Our preliminary research reveals maximum dynamics of traffic intensity in the core areas of the transport regions. Conversely, the boundaries between individual regions (the 
local minimum traffic points) show only very slow dynamics. This supports our assumption that the territorial structure of transport regions is rather stable. Thus, our transport regions might be appropriate for long-term estimations of basic transport-development trends within the transport system of Slovakia.

Nevertheless, confrontation of transport regions with other regionalisation approaches still remains a challenging matter. Comparison with regions of commuting to services would be of special value, since GREEN (1966) postulates that transport regions should correspond significantly to regions of commuting to elementary services. Considering this, some of the empirical studies (e.g., KRAFT, MARAdA \& PopjaKová. 2014) have already brought promising results. Respecting the lack of official data covering commuting to services and due to the growing importance of such interactions, this issue seems to be basic and highly attractive for a future research agenda concerning transport regionalisation.

\section{References}

Ajo R. (1929), Der Verkehrsraum von Tampere [The traffic space of Tampere]. Helsinki, Kansantaloudellinen yhdistys.

BeZÁK A. (1990), Funkčné mestské regióny v sídelnom systéme Slovenska [Functional urban regions in the Slovakian settlement system]. In: Geografický časopis, 42, pp. 57-73.

BezÁk A. (2000), Funkčné mestské regióny na Slovensku [Functional urban regions in Slovakia] (= Geographia Slovaca, 15). Bratislava, Geografický ústav SAV.

BezÁk A. (2001), O regionálnych trhoch práce, nových krajoch a tokoch nezamestnaných [On regional labour markets, new regions and flows of unemployed]. In: Geografický časopis, 53, 4, pp. 295-305.

BeZÁk A. (2014), Priestorová štruktúra systému funkčných mestských regiónov na Slovensku a jej zmeny v desat'rocí 1991-2001 [Spatial structure of functional urban regions in Slovakia and its amendments in the decade 1991-2001]. In: Geographia Cassoviensis, 8, 2, pp. 111-118.

BRANICKÝ M. (1986), Doprava ako element systému infraštruktúry Slovenska [Traffic as an element of the Slovakian infractructure]. Dissertation thesis. Faculty of Natural Sciences, Comenius University in Bratislava.

BranickÝ M., MládeK J. (1991), Transportnyje prostranstvennye obrazovania Slovakii [Transport spatial formations in Slovakia]. In: Acta Facultatis Rerum Naturalium Universitatis Comenianae, Geographica, 31, pp. 157-166.

CASAdo-DíAz J.M., Coombes M. (2011), The delineation of $21^{\text {st }}$ century local labour markets areas: a critical review and a research agenda. In: Boletín de la Asociación de Geógrafos Españoles, 57,pp. 7-32.

Claval P. (2007), Regional geography: past and present (a review of ideas, approaches and goals). In: Geographia Polonica, 80, 1, pp. 25-42.

Coombes M., Openshaw S. (1982), The use and definition of travel-to-work areas in Great Britain: Some comments. In: Regional Studies, 16, 2, pp. 141-149.

Copus A. (2001), From Core-periphery to Polycentric Development: Concepts of Spatial and Aspatial Peripherality. In: European Planning Studies, 9, 4, pp. 539-552.

Dziewoński K. (1967), A theory of economic region. In: Przeglad Geograficzny, 39, pp. 33-50.

FAITH P. (2008), Passenger Road Transport Trends in the Slovak Republic. In: Communications, 10, 3, pp. 33-39. 
GodLund S. (1956), The function and growth of bus traffic within the sphere of urban influence (= Lund Series in Human Geography, 18). Lund, The Royal University of Lund, Gleerup Publishers.

Green F. (1953), Community of Interest Areas in Western Europe: Some Geographical Aspects of Local Passenger Traffic. In: Economic Geography, 29, 4, pp. 283-298.

GreEn F. (1958), Community of interest areas. Notes on the hierarchy of central places and their hinterlands. In: Economic Geography, 34, 3, pp. 210-226.

Green F. (1966), Urban Hinterlands: fifteen years on. In: The Geographical Journal, 132, 2, pp. 263-266.

Halás M., Kladivo P., ŠImáčeK P., Mintálová T. (2010), Delimitation of micro-regions in the Czech Republic by nodal relations. In: Moravian Geographical Reports, 18, 2, pp. 16-22.

Halás M., Klapka P., Bleha B., BednÁŘ M. (2014), Funkčné regióny na Slovensku podl'a denných tokov do zamestnania [Functional regions in Slovakia in terms of daily flows to employment]. In: Geografický časopis, 66, pp. 89-114.

Halás M., ZusKáČová V. (2013), Travelling to services in the daily urban system of Olomouc. In: Bulletin of Geography. Socio-Economic Series, 20, pp. 23-41.

HAMPL M. (2005), Geografická organizace společnosti v České republice: Transformační procesy a jejich obecný context [The geographical organisation of society in the Czech Republic: Transformation processes and their general context]. Praha, UK.

Hampl M., GardavsKÝ V., KüHNL K. (1987), Regional structure and development of the settlement system in Czechoslovakia. Prague, Charles University.

HavlíčEK T., Chromý P., JančÁK V., Marada M. (2008), Innere und äußere Peripherie am Beispiel Tschechiens [Internal and external peripheries by the example of Czechia]. In: Mitteilungen der Österreichischen Geographischen Gesellschaft, 150, pp. 299-316.

HoRŇÁk M., RochovskÁ A. (2014), Do mesta čoraz dalej - dopravné vylúčenie obyvatel'ov vidieckych obcí Gemera [Further and further into the city - traffic exclusion of the inhabitants of rural villages in the commune Gemer]. In: Geographia Cassoviensis, 8, 2, pp. 141-149.

HŮRSKÝ J. (1978), Regionalization of the Czech Socialist Republic based on the gravity of public transport (= Studia Geographica, 59). Brno, Institute of Geography, Czechoslovak Academy of Sciences.

JoRDAN P. (1984), Der Autobusverkehr in den Donauländern - Ergänzungen zu einer Karte im Atlas Donauländer [Bus traffic in the Danubian countries - Supplementations to a map in the Atlas of the Danubian Countries]. In: Österreichische Osthefte, 26, pp. 169-199.

JoRDAN P. (1995), Functional regions in East-Central Europe defined on the basis of the frequency of public bus traffic. In: Geografický časopis/Geographical Journal, 47, 1, pp. 9-15.

Karlsson C., Olsson M. (2006), The identification of functional regions: Theory, methods, and applications. In: Annals of Regional Science, 40, 1, pp. 1-18.

Katuša M., SopkuliaK A. (2013), Dochádzka do zamestnania a dochádzkové regióny SR podl’a SODB 2011 [Commuting and walking regions of Slovakia according to the Census 2011]. In: Potrebuje Slovensko po sčítaní 2011 d’alší cenzus? Zborník príspevkov z medzinárodnej konferencie Štatistického úradu SR, November 20-21, pp. 92-102.

Klapka P., Halás M., Erlebach M., Tonev P., Bednář M. (2014), A multistage agglomerative approach for defining functional regions of the Czech Republic: the use of 2001 commuting data. In: Moravian Geographical Reports, 22, 4, pp. 2-13.

Konjar M., Lisec A., Drobne S. (2010), Method for delineation of functional regions using data on commuters. $13^{\text {th }}$ AGILE International Conference on Geographic Information Science (Guimarães, Portugal), 10 p. - http://plone.itc.nl/agile_old/Conference/2010-guimaraes/ ShortPapers_PDF/93_DOC.pdf(retrieved on 19 May 2015). 
Korec P., Ondoš S., Matu P., Pálková P. (2005), Regionálny rozvoj Slovenska v rokoch 1989-2004 (Identifikácia menej rozvinutých regiónov Slovenska) [Regional development of Slovakia in the years 1989-2004 (Identification of the less developed regions of Slovakia)]. Bratislava, Geografika.

Korec P., Ondoš S. (2006), Less developed regions of Slovakia: Identification and characteristics. In: Acta Geographica Universitatis Comenianae, 46, pp. 55-74.

Korec P., Polonyová E. (2011), Zaostávajúce regióny Slovenska - pokus o identifikáciu a poukázanie na príčiny [Regions lagging behind in Slovakia - an attempt to identify and highlight the causes]. In: Acta Geographica Universitatis Comenianae, 55, 2, pp. 165-190.

Kraft S., Halás M., Vančura M. (2014), The delimitation of urban hinterlands based on transport flows: A case study of regional capitals in the Czech Republic. In: Moravian Geographical Reports, 22, 1,pp. 24-32.

Kraft S., Marada M., Popjaková D. (2014), Delimitation of nodal regions based on transport flows: case study of the Czech Republic. In: Quaestiones Geographicae, 33, 2, pp. 139-150.

KRAFT S., VANČURA M. (2010), Transport concentration areas and their relations to the spatial organization of society: A case study of the Czech Republic. In: Geografický časopis, 62, 4, pp. 279-291.

LAYos L.A. (2005), Short distance passenger mobility in Europe. In: Eurostat, Statistics in Focus Transport, 7 pp., - http://ec.europa.eu/eurostat/

Maryáš J., Kunc J., Tonev P., Szczyrba Z. (2014), Shopping and services related travel in the hinterland of Brno: Changes from the socialist period to the present. In: Moravian Geographical Reports, 22, 3, pp. 18-28.

Michniak D. (2005), Some spatial aspects of commuting in Slovakia in 2001 at the district level. In: Geografický časopis/Geographical Journal, 57, 3, pp. 207-227.

Ministry of Transport, Construction and Regional Development of the Slovak Republic (ed.) (2001), Koncepcia územného rozvoja Slovenska 2001 - KURS 2001 [National Spatial Planning Development Perspective 2001 - NSPDP 2001]. Bratislava.

Novák J., Ahas R., Aasa A., Silm S. (2013), Application of mobile phone location data in mapping of commuting patterns and functional regionalization: a pilot study of Estonia. In: Journal of Maps, 9, 1, pp. 10-15.

NovotNÝ L. (2011), Funkčné mestské regióny najväčších slovenských miest v modeloch urbánneho vývoja [Functional urban regions of the largest Slovak cities in the patterns of urban development]. In: Geographia Cassoviensis, 5, 2, pp. 93-102.

Pucher J., Buehler R. (2005), Transport Policy in Post-Communist Europe. In: Hensher D., Button K. (eds.), Transport Strategies, Policies and Institutions, pp. 725-743. Oxford, Elsevier.

Rinzivillo S., Mainardi S., Pezzoni F., Coscia M., Pedreschi D., Giannotti F. (2012), Discovering the Geographical Borders of Human Mobility. In: Künstliche Intelligenz, 26, 3, pp. 253260.

SäNTTI A. (1954), Autobusverkehr als Indikator der zentralen Orte. Einflussgebiete und Verkehrsdichte in Finnland [Bus traffic as indicator of central places. Catchment areas and traffic density in Finland]. Turku, Annales Universitatis Turkuensis.

Selivanova T.I. (2012), Cheboksary Urban Agglomeration: Delimitation and Analysis. In: Regional Research of Russia, 2, 2, pp. 133-143.

SLAvík V., BAČík V. (2007), Mikroregióny ako podklad ku komunálnej reforme v SR [Micro-regions as a basis for the municipal reform in Slovakia]. In: Geographia Cassoviensis, 1, 1, pp. $169-174$.

SoHN J. (2005), Are commuting patterns a good indicator of urban spatial structure. In: Journal of Transport Geography, 13, 4, pp. 306-317. 
SÝKORA L., MulíčEK O. (2009), The micro-regional nature of functional urban areas (FUAs): lessons from the analysis of Czech urban and regional system. In: Urban Research and Practice, 2, 3 , pp. 287-307.

ŠvedA M. (2010), Zmeny vo využití zeme vo funkčnom mestskom regióne Bratislava [Changes in land use in the functional urban region Bratislava]. In: Acta Geographica Universitatis Comenianae, 54, 1, pp. 137-155.

То́тн V. (2014), Teoretické prístupy k identifikácii vnútornej štruktúry funkčných mestských regiónov na Slovensku [Theoretical approaches to the identification of the internal structure of functional urban regions in Slovakia]. In: Geografický časopis, 66, 4, pp. 363-381.

\section{Other sources:}

Population AND Housing Census 2011

ROAD-TRAFFIC CENSUS 2010

Transport Statistics. Database of the Ministry of Transport, Construction and Regional Development of the Slovak Republic 